contro 24 specie in riduzione o scomparse, mentre, per gli svernanti rispettivamente 52 e 18 in confronto a 1990-1993.

Comunque è risultato evidente che l'attuale modello gestionale del verde pubblico, sempre più artificializzato, e dei coltivi periurbani hanno ricadute negative sull'avifauna della città, e andrebbe quindi modificato per la conservazione della biodiversità rappresentata da questi animali. Ciò è sicuramente proponibile nel governo degli spazi verdi urbani, accompagnandolo con campagne informative ed educative per la cittadinanza, rivolte anche a evitare la persecuzione dell'avifauna, ma è molto più difficile per l'agricoltura, ancor oggi indirizzata quasi esclusivamente verso la quantità dei prodotti anziché verso modelli che includano quanto meno il rispetto delle strutture di base del paesaggio coltivato.

\title{
BIBLIOGRAFIA
}

GroppaLi R., 1993 - Una proposta per la delimitazione esterna dell'area di indagine negli studi sull'avifauna urbana in Italia - Picus, 19: 56-63.

Groppali R., 1994 - Gli Uccelli nidificanti e svernanti nella città di Cremona (1990-1993) - AEM, Museo Civico di Storia Naturale, Cremona. 175 pp.

Groppali R., 2003 - Evoluzione recente di ambienti extraurbani nella Pianura Padana centrale. Aspetti faunistici: l'esempio di Cremona - Pianura, 16: 53-61.

Groppali R., 2005 - Nidificanti e svernanti a Cremona tra 1990-1993 e 2001-2004 - Museo Civico di Storia Naturale, Cremona. 151 pp.

RicCARDO GROPPALI

Dipartimento di Ecologia del Territorio dell’Università - Via S. Epifanio, 14 - I-27100 Pavia

Riv. ital. Orn., Milano, 82 (1-2): 162-164, 30-IX-2013

\section{THE SPARROW PROJECT OF LIPU/BIRDLIFE ITALY}

Riassunto - Il Progetto Passeri della LIPU/BirdLife Italy.

Negli ultimi anni in tutta Europa è stato lanciato l'allarme sulla diminuzione dei passeri (Passera europea, Passera mattugia), soprattutto nelle aree urbane. Anche in Italia i primi dati disponibili, relativi alla Passera d'Italia in città della Lombardia e Toscana, mostrano una diminuzione di circa il 50\% negli ultimi dieci anni. La LIPU ha lanciato il "Progetto Passeri" al fine di promuovere il monitoraggio e lo studio delle popolazioni, la partecipazione al Gruppo di Lavoro internazionale sui passeri, la sensibilizzazione pubblica e azioni di conservazione, anche nell'ambito della pianificazione urbanistica.

\section{Introduction}

Recently alarm on the reduction of

- House Sparrow, Passer domesticus and 
- Tree Sparrow, Passer montanus

in Northern Europe has been issued by BirdLife International.

These species are now classified as SPEC-3 (species of European conservation concern). Decline involves principally urban areas, and varies in magnitude between different areas.

Sparrows in Italy - Four species of the genus Passer occur in Italy:

- House Sparrow, Passer domesticus

- Italian Sparrow, Passer italiae

- Spanish Sparrow, Passer hispaniolensis

- Tree Sparrow, Passer montanus

All these species are breeding in urban areas.

The taxonomic status of the Italian Sparrow has changed over the years: today is considered to be a separate species, and it occupies virtually the same ecological niche as its counterpart the House Sparrows does in the rest of Europe.

Data shows that the most widespreaded and abundant species of the genus Passer in the Italian cities is the Italian Sparrow: it is a common breeder and is the most abundant species in the urban ecosystem (breeding in the 85 principal provincial towns).

The Spanish Sparrow occurs in the cities of Sicily and Sardinia.

The Tree Sparrow situation varies: in some cities it is rare and lives only in the suburbs, in others it is also present in city centres, particularly near green areas of various sizes. This species breeds in 47 principal provincial towns.

The House Sparrow breeds in northern Italy (Aosta and Triest).

Italy also has a special responsibility for the conservation of the Italian Sparrow with most of the world population, and $20 \%$ of the European population of the Spanish Sparrow.

The available data from MITO project on bird monitoring in Italy suggest the following changes in the population indices between 2000 and 2005:

- Italian Sparrow $-27.1 \%$

- Spanish Sparrow -38.5\%

- Tree Sparrow $-10.1 \%$

At the local level, preliminary results from the new edition of the urban Atlas for Livorno (2006) show a decrease in the Italian Sparrow of 53.6\% and the Tree Sparrow of $42.2 \%$ with respect to $1992-93$.

The Sparrow Project - We want to stimulate the start of a specific monitoring programme, regarding urban and rural habitat, and involving also bird-lovers and birdwathers.

For this reason in 2006 LIPU/BirdLife Italy launched the "Sparrow Project" (Progetto Passeri). This is a awareness and information campaign on the ecological problems of urban ecosystem and rural environment.

The planned actions are: 
- the definition of a monitoring programme;

- participation at the European working group on Sparrows;

- the production of a scientific report;

- the spreading of the best practice for the protection of endangered bird populations;

- advice to local governments for urban planning that takes into account biodiversity needs a press campaign and fund raising on the Sparrow Project.

Following are the main actions provided by the Sparrow Project LIPU:

- installation of nest-boxes;

- mitigation the risk of bird-window collision with building and transparent noise-screens along motorways, roads and railways;

- environmental education on urban ecology topics;

- ornithological studies in order to monitor the population of Sparrows;

- awareness programmes and technical advice for municipalities, in order to ecologically improve town planning;

- lobby for excluding Sparrows as hunting species.

\section{DATI PRELIMINARI SULLA DENSITÀ RIPRODUTTIVA DI CALANDRO, ANTHUS CAMPESTRIS, E MAGNANINA COMUNE, SYLVIA UNDATA, NEL PARCO DEL BEIGUA E NELLA ZPS "BEIGUA-TURCHINO" (GE-SV)}

ABSTRACT - Preliminary data on the density of reproductive of Anthus campestris and Sylvia undata found in the Beigua natural park and "Beigua-Turchino" SPA (Liguria, N Italy).

We present the preliminary results concerning the reproductive density of Anthus campestris and Sylvia undata found in the Beigua natural park and "Beigua-Turchino" SPA, during monitoring 2006. The density, determined by the method of detecting the distance with linear transects "Distance Sampling", was found to be 4.57 individuals $/ \mathrm{km}^{2}$ for Anthus campestris and 26.81 individuals $/ \mathrm{km}^{2}$ for Sylvia undata.

\section{Introduzione}

In questo contributo vengono presentati i risultati preliminari relativi alle densità riproduttive di Calandro, Anthus campestris, e Magnanina comune, Sylvia undata, riscontrate, nell'area di studio, durante le attività di monitoraggio svolte nell'anno 2006. 